\title{
Economic feasibility of adding sunflower oil to elephant grass-based diets of lactating dairy cows
}

\section{Viabilidade econômica da inclusão de óleo de girassol em dietas à base de capim-elefante para vacas em lactação}

\author{
Luciana Andrade Lage ${ }^{1}$; Marcos Aurélio Lopes ${ }^{2 *}$; Fernando César Ferraz Lopes ${ }^{3}$; \\ Marco Antônio Sundfeld da Gama ${ }^{3}$; Carlos Gustavo Santos Ribeiro'; \\ Norberto Mario Rodriguez; Fabiana Alves Demeu ${ }^{6}$
}

\begin{abstract}
We aimed to evaluate the economic feasibility of adding increasing levels of sunflower oil $(0.0,15$, 30 , and $45 \mathrm{~g} / \mathrm{kg}$ of dry matter) to elephant grass (Pennisetum purpureum, Schum) based diets of milkproducing Holstein cows. Data were obtained and analyzed for 12 primiparous Holstein cows that produced on average $16.5 \pm 2.8 \mathrm{~kg}$ of milk/day, at $95 \pm 25$ days of lactation. Cows were distributed by milk production, order of lactation, and body weight in a $4 \times 4$ triple Latin square. Isoproteic diets were provided ad libitum in the form of a forage:concentrate ratio of 60:40, on a dry matter basis. Daily milk production was recorded and milk was analyzed for fat, protein, and fatty acids contents. An economic feasibility study was performed considering the price of the supplied ingredients and the daily intake of each diet. The economic benefit was derived by the determining the difference between income from the sale of milk and the cost of animal feed. The quality-based payment was estimated by averaging the systems used by eight dairy companies, based on fat and protein contents and milk volume. The sunflower oil-free diet provided the greatest economic benefit. Adding sunflower oil to elephant grassbased diets was not economically viable because of its associated costs.
\end{abstract}

Key words: Dairy cattle. Economics. Nutrition. Milk quality.

\section{Resumo}

Objetivou-se avaliar a viabilidade econômica da produção de leite de vacas da raça Holandesa, pela inclusão de níveis crescentes de óleo de girassol $(0,0 ; 15 ; 30$ e $45 \mathrm{~g} / \mathrm{kg}$ na matéria seca) em dietas à base de capim-elefante (Pennisetum purpureum, Schum). Os dados analisados foram obtidos de um experimento com 12 vacas primíparas da raça Holandesa, com $95 \pm 25$ dias em lactação, produção média de $16,5 \pm 2,8 \mathrm{~kg} /$ dia de leite, distribuídas em um triplo quadrado latino 4 x 4, conforme a produção de leite, a ordem de lactação e o peso corporal. As dietas foram isoproteicas, fornecidas ad libitum na forma

\footnotetext{
${ }^{1}$ Pós-Graduanda, Departamento de Medicina Veterinária, Universidade Federal de Lavras, UFLA, Lavras, MG, Brasil. E-mail: andradelage@gmail.com

2 Prof. Titular, Dept ${ }^{\circ}$ de Medicina Veterinária, UFLA, Lavras, MG, Brasil. Bolsista do CNPq. E-mail: malopes@dmv.ufla.br

${ }^{3}$ Pesquisadores da Embrapa Gado de Leite, Juiz de Fora, MG, Brasil. E-mail: fernando.lopes@embrapa.br; marco.gama@ embrapa.br

${ }^{4}$ Prof., Instituto Federal de Mato Grosso, Juína, MT, Brasil. E-mail: carlos.ribeiro@jna.ifmt.edu.br

${ }^{5}$ Prof., Escola de Veterinária, Universidade Federal de Minas Gerais, UFMG, Belo Horizonte, MG, Brasil. E-mail: norberto.bhe@, terra.com.br

${ }^{6}$ Prof $\mathrm{f}^{\mathrm{a}}$, Instituto Federal de Rondônia, bolsista CAPES, Doutoranda do programa de Ciências Veterinárias da UFLA, Lavras, MG, Brasil. E-mail: fabiana.alves@ifro.edu.br

* Author for correspondence
} 
de mistura total (relação volumoso: concentrado de 60:40, base matéria seca). A produção diária de leite foi registrada e a composição analisada quanto à concentração de gordura, proteína e ácidos graxos. A viabilidade econômica foi realizada considerando o preço dos ingredientes fornecidos e o consumo diário da dieta de cada tratamento. O benefício econômico foi obtido pela diferença entre a receita, com a venda do leite, e o custo com alimentação dos animais. O pagamento por qualidade foi estimado pela média de sistemas utilizados por oito empresas do ramo de laticínios, com base na concentração de gordura, proteína e no volume de leite. A dieta sem inclusão de óleo de girassol foi a que proporcionou maior benefício econômico. A inclusão de óleo de girassol nas dietas baseadas em capim-elefante não foi viável economicamente, devido aos gastos com este ingrediente.

Palavras-chave: Bovinocultura leiteira. Economia. Nutrição. Qualidade do leite.

\section{Introduction}

The concentration of polyunsaturated fatty acids (FA) in whole milk and milk derivatives could be increased by manipulating the diets of ruminants. This can be achieved for example, by supplying fresh forage of high nutritional quality, either in the form of pasture or as chopped hay fed from a trough, as well as by supplementing the feed with vegetable oils, cakes, and oil seeds rich in oleic, linoleic, and/ or $\alpha$-linolenic FA (LOPES et al., 2015a).

The addition of vegetable-based lipids to the diets of cows is a common practice in intensive milk production systems. The main objective of this practice is to increase the energy density of the diet to meet the requirements of high-producing animals and reduce the consumption of concentrated feeds rich in rapidly rumen-degradable carbohydrates that can cause rumen acidosis and thereby adversely affect performance and health (RIBEIRO et al., 2007). However, a few articles addressing the economic aspects of adding vegetable lipids to the diets of dairy cattle have proven that this nutritional strategy is not economically viable (LOPES et al., 2012; LOPES et al., 2014).

Adding lipids to the diets of cows could help in reducing the synthesis of certain milk components, such as protein and fat (DOREAU; CHILLIARD, 1997). From an economic standpoint, this is important for Brazilian farmers, given that the levels of these components in milk could determine whether they receive bonuses or have to pay fines (DEMEU et al., 2011; PAIXÃO et al.,

\section{4; TEIXEIRA JUNIOR et al., 2015).}

The efforts of milk producers and technicians in the quest to minimize costs have been ongoing, as the industry has now become highly competitive in an uncertain time and environment. Research has shown that animal feed is the most significant expense in milk production (LOPES et al., 2008, 2015b; CARVALHO et al., 2009; SANTOS; LOPES, 2012; FERRAZZA et al., 2015) accounting for as much as $66.49 \%$ of total costs (LOPES et al., 2005). The aim of the present study therefore, was to evaluate the economic feasibility of supplementing elephant grass-based diets with sunflower oil, in lactating Holstein cows. We considered this subject important, because the market prices of vegetable oils are generally higher than those of other ingredients typically added to ruminant diets. Research findings addressing the economic feasibility of ruminant diets are generally lacking and those that specifically focus on the dietary addition of vegetable oils are even fewer.

\section{Materials and Methods}

The analysis of economic feasibility in the present study was based on the study by Ribeiro (2013), who evaluated the effects of supplementing the diets of cows fed chopped elephant grass (Pennisetum purpureum Schum. 'Napier'), and a concentrate (comprising citrus pulp, ground corn, soybean meal, sunflower oil, vitamins, and minerals) with $0,15,30$, and $45 \mathrm{~g} / \mathrm{kg}$ of sunflower oil (SFO) on a dry matter (DM) basis on the intake, production, 
composition, and fatty acid content (FA profile) in the milk. The isoproteic diets were formulated according to NRC (2001) recommendations, to meet the nutritional requirements of a $450 \mathrm{~kg}$ primiparous cow producing $16 \mathrm{~kg}$ of milk with $3.5 \%$ fat, on a daily basis (Table 1).
The diets were fed to 12 primiparous Holstein cows, at $95 \pm 25$ days of lactation, which produced $16.5 \pm 2.8 \mathrm{~kg}$ of milk/day on average. Animals were distributed based on milk yield, lactation order, and body weight in a $4 \times 4$ triple Latin square that was balanced for residual effects.

Table 1. Ingredients and estimated chemical composition of elephant grass-based diets with different levels of added sunflower oil on a dry matter basis.

\begin{tabular}{lcccc}
\hline \multirow{2}{*}{ Ingredients } & \multicolumn{3}{c}{ Level of sunflower oil added (g/kg dry matter) } \\
\cline { 2 - 5 } & $\mathbf{0}$ & $\mathbf{1 5}$ & $\mathbf{3 0}$ & $\mathbf{4 5}$ \\
\hline Elephant grass & 604 & 606 & 605 & 599 \\
Citrus pulp & 108 & 95 & 89 & 82 \\
Ground corn & 108 & 97 & 89 & 82 \\
Soybean meal & 165 & 172 & 171 & 176 \\
Sunflower oil & 000 & 15 & 30 & 45 \\
Vitamin and mineral supplement & 15 & 15 & 15 & 15 \\
\hline Chemical composition ${ }^{1}$ & & & & \\
\hline Crude protein (CP) & 151 & 152 & 15,1 & 152 \\
Ether extract & 21 & 35 & 5,0 & 64 \\
Neutral detergent fiber & 471 & 469 & 466 & 461 \\
Total digestible nutrients (TDN) & 645 & 651 & 657 & 664 \\
\hline
\end{tabular}

${ }^{1}$ Values estimated by the SPARTAN software version 2.0 (Michigan State University, MI, USA)

The cows were housed in free-stall barn, and the individual DM intake was determined daily by using an electronic Calan-gate feed trough (American Calan Inc., Northwood, NH, USA). The diets were provided once daily ad libitum as a total mixture, following routine morning milking.

We recorded individual milk production over two daily milkings (6 A.M. and 2 P.M.). Following homogenization of the milk of each cow, representative samples of individual milk production were collected daily in flasks containing bronopol as a preservative, for the analysis of fat and protein contents. Individual milk samples were also collected in preservative-free flasks, which were then stored at $-20{ }^{\circ} \mathrm{C}$ and subsequently processed for the analysis of rumenic and vaccenic FAs.

Economic feasibility was estimated using the
CU\$TO DIETAS software (LAGE et al., 2011). We considered the income received from the sale of milk (R\$ $0.8929 / \mathrm{kg}$ ) and the cost of each diet. All amounts quoted were based on market prices as at November 2011 in Lavras, MG, Brazil. The economic benefit was calculated as the difference between the income derived from the sale of milk and the cost of animal feed (LOPES et al., 2012).

We conducted a simulation considering the average monetary values of bonuses for milk quality (protein, fat, and fatty acids) and volume, remitted by eight dairy companies. None of the eight companies rewarded farmers for FA levels (hence the values of zero in Table 2, indicating the amounts received for rumenic and vaccenic FA content).

In order to analyze the situations during harvest and off-season, and considering the fact that the 
prices of milk and inputs can fluctuate, we used a three-point estimation technique: best-case estimate, most likely estimate, and worst-case estimate (GROPELLI; NIKBAKHT, 2002). For the most likely estimate, we considered the real scenario, i.e., the market prices at the time of the study. We also simulated worst-case and best-case estimates. For the best-case estimate, the following variables were considered: a) regular price of milk and low prices of inputs; b) high price of milk and low prices of inputs; c) high price of milk and regular prices of inputs. For the worst-case estimate, the following variables were considered: d) regular price of milk and high prices of inputs; e) low price of milk and regular prices of inputs; f) low price of milk and high prices of inputs. We also considered the following alternative estimates: $g$ ) high prices of both milk and inputs; and h) low prices of both milk and inputs, because we could not predict whether they were best-case or worst-case estimates, (LOPES et al., 2014). For the high prices of inputs, we considered the highest prices (from the previous off-season) of ingredients with the largest representation in the diets, namely (17.36\%). For the low prices, we considered price reductions of $24.34 \%, 25.46 \%$, and $5.83 \%$, of the inputs, soybean meal, corn, and SFO, respectively, compared to prices of the estimates at the time of the study. The prices of milk for the most likely, best-case, and worst-case estimates were R \$ $0.8929 ; \mathrm{R} \$ 1.01$ ( R \$ $0.8929+13.53 \%)$; and $\mathrm{R} \$$ 0.77 (R\$ $0.8929-13.53 \%) / \mathrm{kg}$, respectively. All calculations of high and low prices were based on quotations during the off-season and harvest periods (2010-2011), respectively, of the previous year.

Table 2. Production and levels of fat, protein, vaccenic and rumenic fatty acids (FA) in the milk of Holstein cows fed elephant grass-based diets (on a dry matter basis), supplemented with different levels of sunflower oil (SFO) and prices $\left(\mathrm{R} \$\right.$ ) paid per kg of milk, protein, fat, and FA content ${ }^{1}$.

\begin{tabular}{ccccccccccc}
\hline $\begin{array}{c}\text { Addition } \\
\text { of SFO } \\
(\mathrm{g} / \mathrm{kg})\end{array}$ & \multicolumn{2}{c}{ Volume } & \multicolumn{2}{c}{ Protein } & \multicolumn{2}{c}{ Fat } & \multicolumn{2}{c}{ Vaccenic FA } & \multicolumn{2}{c}{ Rumenic FA } \\
\cline { 2 - 11 } & $\mathrm{R} /$ day & $\%$ & $\mathrm{R} \$ *$ & $\%$ & $\mathrm{R} \$^{*}$ & $\begin{array}{c}\mathrm{g} / 100 \mathrm{~g} \\
\text { of FA }\end{array}$ & $\mathrm{R} \$ *$ & $\begin{array}{c}\mathrm{g} / 100 \mathrm{~g} \\
\text { of FA }\end{array}$ & $\mathrm{R} \$^{*}$ \\
\hline 0 & 14.9 & 0.8929 & 2.72 & -0.0169 & 3.36 & +0.0023 & 1.83 & 0.0000 & 0.87 & 0.0000 \\
15 & 14.9 & 0.8929 & 2.73 & -0.0169 & 3.51 & +0.0043 & 3.11 & 0.0000 & 1.22 & 0.0000 \\
30 & 14.4 & 0.8929 & 2.74 & -0.0169 & 3.56 & +0.0043 & 4.39 & 0.0000 & 1.61 & 0.0000 \\
45 & 14.9 & 0.8929 & 2.72 & -0.0169 & 3.59 & +0.0043 & 5.73 & 0.0000 & 2.13 & 0.0000 \\
\hline
\end{tabular}

${ }^{1}$ Volume and milk composition data (RIBEIRO, 2013).

*Considering the average values paid by eight dairy companies in 2011; vaccenic FA (C18:1 trans-11); rumenic FA (conjugated linoleic acid [CLA] cis-9-trans-11).

\section{Results and Discussion}

The inclusion of SFO did not affect DM intake, milk production, fat or protein contents $(\mathrm{kg} / \mathrm{cow} /$ day), nor the percentage of milk protein, which is consistent with the results of Ribeiro (2013). On the other hand, a linear increase $(P=0.0015)$ in milk fat percentage was noted as a result of SFO supplementation. The concentrations of vaccenic and rumenic FAs in milk fat also increased in a linear manner $(\mathrm{P}<0.0001)$ with increasing levels of SFO supplementation (Table 3), indicating milk production with nutraceutical potential (Table 3).

An SFO-free diet was considered more economically viable, because it was associated with lower feed costs (R\$ 4.14) and greater economic benefits (R\$ 9.16/cow/day) than SFO-supplemented diets (Table 3). Soybean meal had the greatest impact on the cost of the feed at 0,15 , and $30 \mathrm{~g} / \mathrm{kg}$ SFO. However, despite the use of low SFO levels (in relation to other ingredients), at a higher level 
of supplementation $(45 \mathrm{~g} / \mathrm{kg})$, it became the main factor responsible for increasing feed costs, owing to its high cost per kilogram of DM $(\mathrm{R} \$ 5.38)$ (Table 4).

The lowest feed cost $/ \mathrm{kg}$ of milk produced (Table 5) was observed with SFO-free feeding (R\$ 0.2779). SFO supplementation tended to make diets more expensive. There was a cost difference of $\mathrm{R} \$ 0.1698$ (R\$ 0.4477 - R \$ 0.2779; Table 5) between the highest and the lowest level of SFO per kg of milk produced. This difference represents a considerable increase in feed costs, which in turn increases production costs and can vary from $52.23 \%$ (LOPES et al., 2008) to $66.49 \%$ (LOPES et al., 2005).

Table 3. Average daily intake, milk yield and composition, income, feed cost, and economic benefit of Holstein cows fed elephant grass-based diets with different levels of added sunflower oil.

\begin{tabular}{|c|c|c|c|c|c|}
\hline \multirow{2}{*}{ Variable } & \multicolumn{5}{|c|}{$\begin{array}{l}\text { Level of added sunflower oil } \\
\text { (g/kg dry matter) }\end{array}$} \\
\hline & $\mathbf{0}$ & 15 & 30 & 45 & $\begin{array}{l}\text { P-value for } \\
\text { linear effect }\end{array}$ \\
\hline A- Dry matter intake (kg/cow/day)' & 10.8 & 11.5 & 10.8 & 11.1 & 0.9545 \\
\hline B- Milk production (kg/cow/day)' & 14.9 & 14.9 & 14.4 & 14.9 & 0.7241 \\
\hline C- Protein production $(\mathrm{kg} / \mathrm{cow} / \mathrm{day})^{\prime}$ & 0.403 & 0.403 & 0.391 & 0.405 & 0.9027 \\
\hline D- Protein content $(\%)^{\prime}$ & 2.72 & 2.73 & 2.74 & 2.72 & 0.7556 \\
\hline E- Fat production (kg/cow/day)' & 0.499 & 0.523 & 0.513 & 0.530 & 0.2539 \\
\hline F- Fat content $(\%)^{\prime}$ & 3.36 & 3.51 & 3.56 & 3.59 & 0.0015 \\
\hline G- Vaccenic acid content ( $\mathrm{g} / 100 \mathrm{~g}$ of total fatty acids) ${ }^{1}$ & 1.83 & 3.11 & 4.39 & 5.73 & $<0.0001$ \\
\hline H- Rumenic acid content (g/100 g of total fatty acids) ${ }^{1}$ & 0.87 & 1.22 & 1.61 & 2.13 & $<0.0001$ \\
\hline I- Milk income/cow/day $(\mathrm{R} \$)^{2}$ & 13.30 & 13.30 & 12.86 & 13.30 & \\
\hline J- Feed cost/cow/day $(\mathrm{R} \$)^{3}$ & 4.14 & 5.22 & 5.64 & 6.67 & \\
\hline K- Economic benefit/cow/day $(\mathrm{R} \$)^{4}$ & 9.16 & 8.08 & 7.22 & 6.63 & \\
\hline
\end{tabular}

${ }^{1}$ Source: Ribeiro (2013); ${ }^{2}(\mathrm{I}=\mathrm{B} \times \mathrm{R} \$ 0.8929) ;{ }^{3}$ (total intake of each ingredient based on $\mathrm{DM} \times$ price $/ \mathrm{kg}$ of each ingredient $) ;{ }^{4}(\mathrm{~K}=$ $\mathrm{I}-\mathrm{J})$.

Table 4. Price of inputs in the diets per $\mathrm{kg}$ and $\mathrm{R} \$ / \mathrm{cow} / \mathrm{day}$, and percentage of each ingredient in the total of each diet/ cow/day.

\begin{tabular}{|c|c|c|c|c|c|c|c|c|c|}
\hline \multirow{3}{*}{ Ingredient } & \multirow{3}{*}{$\begin{array}{l}\text { Price }^{*} \\
(/ \mathbf{k g})\end{array}$} & \multicolumn{8}{|c|}{ Level of sunflower oil added (g/kg dry matter) } \\
\hline & & \multicolumn{2}{|c|}{$\mathbf{0}$} & \multicolumn{2}{|c|}{15} & \multicolumn{2}{|c|}{30} & \multicolumn{2}{|c|}{45} \\
\hline & & $\begin{array}{c}\mathbf{R} \$ / \\
\text { cow/day }\end{array}$ & $\mathbf{g} / \mathbf{k g}^{* *}$ & $\begin{array}{c}\mathrm{R} \$ / \\
\text { cow/day }\end{array}$ & $\mathrm{g} / \mathrm{kg}^{* *}$ & $\begin{array}{c}\mathbf{R} \$ / \\
\text { cow/day }\end{array}$ & $\mathrm{g} / \mathrm{kg}^{* *}$ & $\begin{array}{c}\mathrm{R} \$ / \\
\text { cow/day }\end{array}$ & $\%^{* * *}$ \\
\hline Ground corn & 0.69 & 0.81 & 195.2 & 0.78 & 149.4 & 0.66 & 117.2 & 0.63 & 22.4 \\
\hline Soybean meal & 0.95 & 1.72 & 414.5 & 1.89 & 362.1 & 1.76 & 312.6 & 1.86 & 216.6 \\
\hline Citrus pulp & 0.58 & 0.68 & 163.9 & 0.65 & 124.5 & 0.56 & 99.5 & 0.53 & 156.9 \\
\hline Minerals/vitamins & 1.73 & 0.28 & 67.5 & 0.29 & 55.6 & 0.28 & 49.7 & 0.29 & 28.8 \\
\hline Sunflower oil & 5.38 & 0.00 & 0.00 & 0.91 & 174.3 & 1.72 & 305.5 & 2.69 & 384.2 \\
\hline Elephant grass & 0.10 & 0.66 & 159.0 & 0.70 & 134.1 & 0.65 & 115.5 & 0.67 & 167.6 \\
\hline TOTAL & & 4.14 & 1000 & 5.22 & 1000 & 5.64 & 1000 & 6.67 & 1000 \\
\hline
\end{tabular}

${ }^{*}$ Estimated in November 2011, in the southern region of the state of Minas Gerais, Brazil; **; price of the ingredient/dietary value) $\times 100$. 
A payment simulation for milk quality was performed considering the average prices paid by eight dairy companies in the region. As a result, all diets would have incurred a penalty of $\mathrm{R} \$-0.0169$ / $\mathrm{kg}$ of milk, owing to milk protein contents between $2.72 \%$ and $2.74 \%$. The SFO-free diet would have been subsidized at $\mathrm{R} \$ 0.0023 / \mathrm{kg}$ of milk, for a fat content of $3.36 \%$, whereas the other diets would have been subsidized at $\mathrm{R} \$ 0.0043$ for fat contents between $3.51 \%$ and $3.59 \%$ (Table 5).

The SFO-free diet was the most economically viable, as it showed the greatest economic benefit (Table 5). In a hypothetical herd of 50 cows with an average milk production of $14.7 \mathrm{~kg} / \mathrm{cow} /$ day, a difference in economic benefit of $\mathrm{R} \$ 0.1678 /$ $\mathrm{kg}$ of milk ( $\mathrm{R} \$ 0.6004-\mathrm{R} \$ 0.4326$ between the diets containing 45 and $0 \mathrm{~g} / \mathrm{kg}$ SFO, respectively) would accrue $\mathrm{R} \$ 3,699.99$ per month $(\mathrm{R} \$ 0.1678$ $\times 50$ cows $\times 14.7 \mathrm{~kg} /$ cow/day $\times 30$ days $)$, making it economically attractive. This finding shows that positive economic impacts are achieved by not only increased production and/or changes in milk composition, but in this case, particularly, by reduced feed costs. Research has shown that among the factors contributing to the effective operational costs of milk production, feed has the greatest impact (LOPES et al., 2005, 2008; SANTOS; LOPES, 2012).

Table 5. Feed costs; bonuses for protein, fat, and fatty acid contents; income; and economic benefit per kg of milk and cow/day associated with elephant grass-based diets supplemented with sunflower oil.

\begin{tabular}{lcccc}
\hline \multirow{2}{*}{ Item } & \multicolumn{4}{c}{ Level of sunflower oil added (g/kg of dry matter) } \\
\cline { 2 - 5 } & $\mathbf{0}$ & $\mathbf{1 5}$ & $\mathbf{3 0}$ & $\mathbf{4 5}$ \\
\hline A- Feed cost/kg of milk $(\mathrm{R} \$)$ & 0.2779 & 0.3503 & 0.3917 & 0.4477 \\
B- Payment and bonus/kg/milk $(\mathrm{R} \$)^{*}$ & 0.8929 & 0.8929 & 0.8929 & 0.8929 \\
C- Bonus for protein content/kg/milk $(\mathrm{R} \$)^{*}$ & -0.0169 & -0.0169 & -0.169 & -0.0169 \\
D- Bonus for fat content/kg/milk (R\$) & 0.0023 & 0.0043 & 0.0043 & 0.0043 \\
E- Bonus for fatty acids & 0.0000 & 0.0000 & 0.0000 & 0.0000 \\
F- Income $(\mathrm{R} \$ / \mathrm{kg})(\mathrm{B}+\mathrm{C}+\mathrm{D}+\mathrm{E})$ & 0.8783 & 0.8803 & 0.8803 & 0.8803 \\
G- Economic benefit $(\mathrm{R} \$ \mathrm{~kg})(\mathrm{F}-\mathrm{A})$ & 0.6004 & 0.5299 & 0.4886 & 0.4326 \\
H- Production $(\mathrm{kg} /$ day) & 14.9000 & 14.9000 & 14.4000 & 14.9000 \\
I- Economic benefit cow/day $(\mathrm{R} \$)(\mathrm{G} \times \mathrm{H})$ & 8.9642 & 7.8960 & 7.0359 & 6.4460 \\
\hline
\end{tabular}

${ }^{*}$ Criteria based on the average price paid by eight dairy companies from the southern region of the state of Minas Gerais, Brazil in 2011 .

The additional costs associated with feed containing SFO (Table 6) represents the difference between the feed cost/cow/day of the respective levels of supplementation (Table 3) and the SFO-free diet. The bonuses earned based on fat content and FA levels did not compensate for the additional expense of SFO supplementation in the experimental diets and resulted in negative balances for feeds containing 15,30 , and $45 \mathrm{~g} / \mathrm{kg}$ SFO. This fact highlights the economic unfeasibility of adding SFO to the experimental diets (Table 6). Similar results have been obtained by Lopes et al. (2012), who analyzed the economic feasibility of adding soybean oil to elephant grass-based diets, and Lopes et al. (2014), who evaluated SFO supplementation in sugarcane-based diets of lactating cows.

Despite the differences observed in vaccenic and rumenic acid contents in milk (Table 3), because no bonus is earned from the FA content of milk in Brazil, it is not economically viable to add SFO to the diets of dairy cows. Based on market forecasts, the dairy industry is expected to strive to find 
innovative feed products that are not only safe and free of contaminants and residues, but also those that have nutraceutical potential, which have been tested for composition, quality, and purity (LOPES et al., 2014). In Brazil, superior milk quality has become synonymous with products derived from a complete process of undisturbed milking routines and hygienic conditions of healthy, wellfed and well-rested cows, that meet the guidelines established by the Normative Instruction 62 (BRASIL, 2011). These guidelines differ somewhat from those adopted by other countries that have become increasingly concerned about the trade of healthier products (DÓNEGA, 2010; LOPES et al., 2015a).

According to Lopes et al. (2014), a bonus payment for the production of milk that is naturally enriched with FAs and has positive effects on human health (e.g., with higher levels of rumenic and vaccenic acids) could benefit the entire production chain. The dairy producers would receive higher incomes; groceries and supermarkets could earn competitive prices for the trade of innovative products; and consumers would benefit from better quality products. In Brazil however, milk and dairy commodities with such marketing appeal have not been produced in recent times, neither has there been any initiative of the dairy industry to implement payment subsidy policies for rural entrepreneurs who produce such superior products (LOPES et al., 2015a).

The results are relative to a real scenario, with prices from November 2011. Because the prices of milk and inputs fluctuate throughout the year, we used a three-point estimation technique: bestcase estimate, most likely estimate, and worst-case estimate, (GROPELLI; NIKBAKHT, 2002). In all scenarios under investigation, penalties would have been imposed, because there was no economic benefit to supplementing the diets with SFO. These findings suggest the importance of formulating low-cost diets, and the need to manipulate certain milk components. Lopes et al. (2012) suggested that in addition to the payment policies presently adopted by several dairy companies in relation to somatic cell and total bacterial counts and protein and fat contents, bonuses should also be paid to farmers as an incentive to produce milk with nutraceutical potential that would benefit the health of consumers.

\section{Conclusions}

Adding sunflower oil to elephant grass-based diets of Holstein cows is not economically viable because of the expenses associated with the purchase of this dietary supplement.

\section{Acknowledgement}

The authors thank FAPEMIG and CNPq for supporting this study.

\section{References}

BRASIL. Ministério da Agricultura, Pecuária e Abastecimento. Instrução normativa $\mathrm{n}^{\circ} 62$, de 29 de dezembro de 2011. Regulamento técnico de produção, identidade e qualidade do leite tipo A, regulamento técnico de identidade e qualidade de leite cru refrigerado, o regulamento técnico de identidade e qualidade de leite pasteurizado e o regulamento técnico da coleta de leite cru refrigerado e seu transporte a granel. Diário Oficial [da] União, Brasília, 2011. Seção 1, p. 1-24.

CARVALHO, F. de M.; RAMOS, O. E.; LOPES, M. A. Análise comparativa dos custos de produção de duas propriedades leiteiras no município de Unaí - MG, no período de 2003 e 2004. Ciência e Agrotecnologia, Lavras, v. 33, p. 1705-1711, 2009. Edição Especial.

DEMEU, F. A.; LOPES, M. A.; COSTA, G. M.; ROCHA, C. M. B. M.; SANTOS, G.; FRANCO NETO, A. Influência do descarte involuntário de matrizes no impacto econômico da mastite em rebanhos leiteiros. Ciência e Agrotecnologia, Lavras, v. 35, n. 1, p. 195-202, 2011.

DÓNEGA, J. M. Innovácion em PYMES del sector lácteo. In: VILELA, D.; FERNANDES, E. N.; ZOCCAL, $\mathrm{R}$. et al. (Ed.). Estratégias e conhecimentos para o fortalecimento do agronegócio do leite. Juiz de Fora, MG: Embrapa Gado de Leite, 2010. p. 85-95. 
DOREAU, M.; CHILLIARD, Y. Digestion and metabolism of dietary fat in farm animal. British Journal of Nutrition, Cambridge, v. 78, p. S15-S35, 1997. Supplement 1.

FERRAZZA, R. A.; LOPES, M. A.; MORAES, F.; BRUHN, F. R. P. Índices de desempenho zootécnico e econômico de sistemas de produção de leite com diferentes níveis tecnológicos. Semina: Ciências Agrárias, Londrina, v. 36, n. 1, p. 485-496, 2015.

GROPELLI, A. A.; NIKBAKHT, E. Administração financeira. 2. ed. São Paulo: Saraiva, 2002. 512 p.

LAGE, L. A.; LOPES, M. A.; REIS, M. P.; SANTOS, G. Desenvolvimento de um sistema computacional para avaliação do custo:benefício de diferentes dietas na atividade leiteira. In: REUNIÃO ANUAL DA SOCIEDADE BRASILEIRA DE ZOOTECNIA, 48., 2011, Belém. Anais... Belém: SBZ, 2011. p. 1-3.

LOPES, F. C. F.; SILVA, B. C. M.; ALMEIDA, M. M.; GAMA, M. A. S. Lácteos naturalmente enriquecidos com ácidos graxos benéficos à saúde. In: MARTINS, P. C.; PICCININI, G. A.; KRUG, E. E. B.; MARTINS, C. E.; LOPES, F. C. F. (Org.). Sustentabilidade ambiental, social e econômica da cadeia produtiva do leite: desafios e perspectivas. Brasília, DF: Embrapa, p. 237-309. 2015a.

LOPES, M. A.; LAGE, L. A.; LOPES, F. C. F.; GAMA, M. A. S. da; SOUZA, S. M. Viabilidade econômica da inclusão de óleo de girassol em dieta à base de canade-açúcar para vacas em lactação. Arquivo Brasileiro Medicina Veterinária e Zootecnia, Belo Horizonte, v. 66, n. 3, p. 853-860, 2014.

LOPES, M. A.; LAGE, L. A.; LOPES, F. C. F.; RIBEIRO, C. G. S.; GAMA, M. A. S.; RODRIGUEZ, N. M. Economic viability of feeding dairy cows on diets containing different levels of soybean oil. Revista Brasileira de Zootecnia, Viçosa, MG, v. 41, n. 9, p. 20852091, 2012.

LOPES, M. A.; LIMA, A. L. R.; CARVALHO, F. M.; REIS, R. P.; SANTOS, I. C.; SARAIVA, F. H. Resultados econômicos de sistemas de produção de leite com diferentes níveis tecnológicos na região de Lavras, MG. Arquivo Brasileiro Medicina Veterinária e Zootecnia, Belo Horizonte, v. 57, n. 4, p. 485-493, 2005.
LOPES, M. A.; MORAES, F. de; CARVALHO, F. M.; PERES, A. C. C.; BRUHN, F. R. P.; REIS, E. M. B. The effect of technological levels on profits of milk production systems participating in the "full bucket" program: a multicase study. Semina: Ciências Agrárias, Londrina, v. 36, n. 4, p. 2909-2922, 2015 b.

LOPES, M. A.; SANTOS, G.; AMADO, G. B. Viabilidade econômica da adoção e implantação da rastreabilidade em sistema de produção de bovinos no estado de Minas Gerais. Ciência e Agroecnologia, Lavras, v. 32, n. 1, p. 288-294, 2008.

NATIONAL RESEARCH COUNCIL - NRC. Nutrients requirements of dairy cattle. $7^{\text {th }} \mathrm{ed}$. Washington: National Academy Press, 2001. 381 p.

PAIXÃO, M. G.; LOPES, M. A.; PINTO, S. M.; ABREU, L. R. de. Impacto econômico da implantação das boas práticas agropecuárias relacionadas à qualidade do leite. Revista Ceres, Viçosa, MG, v. 61, n. 5, p. 612-621, 2014.

RIBEIRO, C. G. S. Produção e composição do leite de vacas alimentadas com capim-elefante suplementado com óleo de girassol. 2013. Tese (Doutorado em Zootecnia) - Universidade Federal de Minas Gerais, Escola de Veterinária, Belo Horizonte.

RIBEIRO, C. G. S.; GAMA, M. A. S.; LOPES, F. C. F.; CARNEIRO, J. C.; RIBEIRO, M. T.; RODRIGUEZ, N. M.; REIS, R. B.; VERNEQUE, R. Desempenho e composição do leite de vacas mestiças recebendo dietas baseadas em forragem tropical suplementadas com diferentes níveis de óleo de soja. In: REUNIÓN DA ASOCIACIÓN LATINOAMERICANA DE PRODUCCIÓN ANIMAL, 20., 2007, Cuzco. Anais... Cuzco: ALPA, 2007. p. 1-1.

SANTOS, G.; LOPES, M. A. Indicadores de rentabilidade do centro de custo produção de leite em sistemas intensivos de produção. Boletim da Indústria Animal, Nova Odessa, v. 69, n. 1, p. 1-11, 2012.

TEIXEIRA JÚNIOR, F. E. P.; LOPES, M. A.; RUAS, J. R. M. Efeito do pagamento por qualidade do leite na rentabilidade da atividade leiteira. Revista do Instituto de Laticinios Cândido Tostes, Juiz de Fora, v. 70, n. 1. p. 24-34, 2015. 